\title{
Empirické přístupy $\mathbf{v}$ sociálně stratifikačním výzkumu vzdělanostních nerovností
}

\author{
NATALIE SIMONOVÁ*,** \\ Sociologický ústav AV ČR, v.v.i., Praha \\ TOMÁŠ KATRŇÁK ${ }^{* * * *}$ \\ Fakulta sociálních studií Masarykovy univerzity, Brno

\section{Empirical Approaches in Social Stratification Research on Educational Inequalities}

\begin{abstract}
This article provides a look at the main turning points in research on educational inequalities, both at the level of the field's subject matter and its methodology. The text focuses on authors and concepts that in their time constituted a major innovation, significantly advancing analysis and knowledge in the field of research on educational inequalities. In the article the authors propose viewing researchers in the field of educational inequalities through the lens of their era and in relation to the major turning points between them, which can be identified in terms of subject matter and methodology, and even chronologically. The authors define three basic periods, and for each one present two key concepts. The first period is represented by the basic model of the stratification process and by the socio-psychological model. The second period is characterised by the concept of educational allocation and the theory of 'maximally maintained inequality' (MMI). Presented for the third period are the multinomial transition model and the theory of 'effectively maintained inequality' (EMI). Across these stages of development the authors highlight three of the cited concepts as ground-breaking methodological innovations (the basic model of the stratification process, the concept of educational allocation, and the multinomial transition model) and the other three as innovations in subject matter (interpretive), though closely tied to the advancement of quantitative methods used in the analysis of educational inequalities (the socio-psychological model and the MMI and EMI theories).
\end{abstract}

Keywords: access to education, educational inequality, educational research, measures of inequality.

Sociologický časopis/Czech Sociological Review, 2008, Vol. 44, No. 4: 725-743

\footnotetext{
* Veškerou korespondenci posílejte na adresu: PhDr. Natalie Simonová, Sociologický ústav AV ČR, v.v.i., Jilská 1, 110 00, Praha 1, e-mail: natalie.simonova@soc.cas.cz, nebo PhDr. Tomáš Katrňák, Ph.D., Fakulta sociálních studií MU, Brno, Joštova 10, 602 00, Brno, e-mail: katrnak@fss.muni.cz.

** Práce na této stati byla umožněna díky grantové podpoře projektu „Vzdělanostní mobilita a vzdělanostní nerovnosti v České republice mezi lety 1936 až 2004“ (GA ČR
} 


\section{Úvod}

Jednou z nejdůležitějších otázek, se kterou se výzkum vzdělanostní dimenze sociální stratifikace intenzivně potýká přinejmenším od druhé poloviny 20. století, je zásluhovost dosahování vzdělanostního statusu. Impulzem k jeho zkoumání nesporně byly hluboké společenské změny započaté $\mathrm{v}$ době průmyslové revoluce a zdynamizované po druhé světové válce. Značné sociální a ekonomické změny se promítly do chápání role vzdělání ve společnosti, o kterém se začalo uvažovat jako o mediátoru mezi schopnostmi a výsledným společenským postavením. Díky industrializaci, která měla za následek dlouhodobý přesun z primárního sektoru hospodářství (zemědělství, lesnictví, těžba) do sekundárního sektoru (průmysl), a ze sekundárního do terciálního sektoru (služby), poklesl počet nekvalifikovaných zemědělských a manuálních dělníků a vzrostl počet dělníků nemanuálních, dále odborníků, úředníků a manažerů. Souběžným doprovodným jevem byl posun $\mathrm{v}$ distribuci tři stěžejních statusových atributů: vzdělání, povolání a př́ijmu - vše začalo být $\mathrm{v}$ mnohem větší míře determinováno výkonem (vzděláním) a méně již sociálním původem. Rostoucí poptávka po kvalifikované pracovní síle totiž vedla ke zvýšení dostupnosti vzdělání a díky růstu vzdělanostních př́ležitostí poklesl vliv sociálního původu na stupeň dosaženého vzdělání jedince [Treiman 1970].

Díky měření dostupnosti vzdělání a jeho role v procesu dosahování statusu bylo možné prosazovat takové politiky, které by podporovaly nejen zvyšování efektivity jednotlivých ekonomik, ale i sociální spravedlnost. Výzkum vzdělanostních nerovností si proto s sebou implicitně nese definici rovnosti a spravedlnosti v přístupu ke vzdělání. Rovnost v přístupu ke vzdělání je nejčastěji chápána jako rovnost $\mathrm{v}$ př́istupu ke vzdělání srovnatelné kvality (tj. se stejnými podmínkami vzdělávání a stejnými pravidly pro dosažení úspěchu). Za takových okolností je výslednou nerovnost možno považovat za spravedlivou, protože je výsledkem odlišných individuálních schopností, úsilí a výsledného výkonu, tj. výsledný systém je možné označit za meritokratický (bližší výklad současného pojetí spravedlnosti ve vzdělávání podávají nap̌r. [Hutmacher, Cochrane, Bottani 2001]). Rozdíly ve studijních výsledcích jsou tak omezeny na nutné minimum, jakožto důsledek osobních dispozic, nikoli socializace či lepší/horší školy. V empirických analýzách však není tak snadno identifikovatelné, kde končí zátěž sociálního původu a otevírá se pole, v němž se již uplatňují pouze specifické schopnosti, nadání či talent.

403/06/1241). Práce N. Simonové byla rovněž umožněna díky pobytu v European Centre for Analysis in the Social Sciences (ECASS) v Institute for Social and Economic Research (ISER) na University of Essex, financovanému "Access to Research Infrastructure Action" v rámci programu Evropské unie „Improving Human Potential Programme“. Práce Tomáše Katrňáka na této studii byla umožněna také díky výzkumnému záměru „Reprodukce a integrace společnosti“ (MSM0021622408) při Fakultě sociálních studií Masarykovy univerzity v Brně. 
V tomto textu se zaměříme na jednotlivá řešení tohoto problému. Protože výčet všech odborníků zabývajících se výzkumem vzdělanostních nerovností v rámci sociálně stratifikačního výzkumu by zdaleka přesáhl možnosti této stati, budeme se soustředit pouze na nejdůležitější okamžiky v jeho nedlouhé historii, a sice na věcně-metodologické inovace ve zkoumání vzdělanostních nerovností. Jelikož mezi nimi najdeme poměrně ostré předěly jak z hlediska koncepčního, tak statisticko-metodologického, navrhujeme historii výzkumu vzdělanostních nerovností rozčlenit do tř́ období. ${ }^{1}$ První spadá do šedesátých a sedmdesátých let minulého století a charakterizuje ho základní model stratifikačního procesu [Blau, Duncan 1967] a model sociálně-psychologický [Sewell, Shah 1967; Hauser, Tsai, Sewell 1983]. Z hlediska metodologického mají analýzy vzdělanostních nerovností $\mathrm{v}$ tomto období oporu $\mathrm{v}$ lineární regresi, rozpracované do pěšinkové („,path“) analýzy. Druhé období spadá do osmdesátých a devadesátých let minulého století a zásadní přínos $\mathrm{v}$ něm znamenaly koncept alokace vzdělání [Mare 1980] a teorie maximálně udržované nerovnosti - „maximally maintained inequality“ (MMI) [Raftery, Hout 1993]. Z hlediska metodologického jsou analýzy tohoto období opřeny o sekvenční model logistické regrese vzdělanostních přechodů. A konečně třetí období časově lokalizujeme do první dekády století jednadvacátého. Je vymezeno multinomiálním modelem vzdělanostních tranzicí [Breen, Jonsson 2000] a teorií nerovnosti udržované ve výsledku - „effectively maintained inequality" (EMI) [Lucas 2001]. Následující text čtenáře nejprve stručně uvede do teoretického zázemí empirického měření vzdělanostních nerovností a poté představí jednotlivá období zkoumání vzdělanostních nerovností - nejprve z hlediska věcného, a poté $\mathrm{z}$ hlediska statisticko-metodologického.

\section{Teoretické a empirické přístupy $k$ vysvětlení vzniku a reprodukce vzdělanostních nerovností}

Existuje poměrně široká paleta teorií, které vysvětlují, jak se vzdělanostní nerovnosti utvářejí a reprodukují. Ti autoři, kteří jsou nejčastěji označováni za stoupence teorie kulturní reprodukce, považují ustavené společenské nerovnosti za příčinu i motor následné školní selekce. Mechanismy, které podle těchto autorů zprostředkovávají reprodukci vzdělanostních nerovností, představují např. rozdílné způsoby komunikace, zejména stupeň její abstrakce [Bernstein 1975; Heath 1983], osvojování si kontraškolní kultury př́slušníky dělnických vrstev [Willis

\footnotetext{
${ }^{1} \mathrm{~V}$ sociálně stratifikačním výzkumu se etabloval koncept čtyř generací, které se mezi sebou liší způsobem analýzy dat, jejich povahou, typem výzkumných problémů, hypotéz a výzkumných zjištění [Ganzeboom, Treiman, Ultee 1991; Treiman, Ganzeboom 2000; Katrňák 2005]. Historie výzkumu vzdělanostních nerovností se s historií sociálně stratifikačního výzkumu částečně překrývá, nicméně ji zcela nekopíruje. $Z$ tohoto důvodu nelze koncept generací vymezených v sociálně stratifikačním výzkumu mechanicky aplikovat na výzkum vzdělanostních nerovností.
} 
1977] či třídně determinovaná inklinace $\mathrm{k}$ ideologii úspěchu [MacLeod 1995]. Autoři, kteří jsou oproti tomu označováni za stoupence teorie sociální reprodukce, považují školu a školní selekci za přičinu společenské nerovnosti - jsou pro ně nástrojem státu sloužícím k socializaci dětí do tř́́d, z nichž pocházejí. Školy podle nich jednají např. v zájmu ideologie státu [Althusser 1971], podle principu korespondence s kapitalistickým ekonomickým systémem [Jencks 1972; Bowles, Gintis 1976] nebo pouze posvěcují intergenerační přenos hodnot, specifických pro každou sociální tř́du [Kohn 1977]. Obě tyto perspektivy, tj. kulturní i sociální reprodukce, spojuje důraz na lingvistické schopnosti a kulturní znalosti, které jsou ve škole transformovány do podoby osobních zásluh a jsou zároveň dominantním předpokladem úspěchu v ní [Bourdieu, Passeron 1964; Bourdieu 1973]. V neposlední řadě lze výsledek působení škol v kapitalistické společnosti vidět poněkud vyhrocenou optikou jakožto pasivní konzumaci společenského řádu, kterou je možné překonat pouze odškolněním společnosti [Illich 2000].

Všechny tyto teoretické koncepty jsou důležitým (i když nikoli dokonalým) nástrojem vysvětlení vzniku a reprodukce vzdělanostních nerovností. Nutným předpokladem identifikace mechanismů dosahování vzdělanostního statusu je empirická analýza vzdělanostních nerovností - měření vzdělanostních nerovností $\mathrm{v}$ jednotlivých sociálních třídách, společnostech a v čase. Způsoby měření vzdělanostních nerovností se od druhé poloviny 20. století poměrně rychle vyvíjejí a zdokonalují - dodnes se jich $\mathrm{v}$ rámci sociologie vzdělání vystřídalo hned několik. $\mathrm{Z}$ dnešního úhlu pohledu proto již můžeme hovořit o vývoji na tomto poli bádání. Jednotlivé způsoby měření na sebe navazují, každý následující přístup vychází z nedokonalostí přístupu předcházejícího a je navržen tak, aby jej korigoval. Automaticky to však neznamená, že by časově starší přistupy byly s uvedením nového opuštěny a nebyly sociálními vědci pro analýzu vzdělanostních nerovností již vưbec využívány.

V následujícím textu se pokusíme tento vývoj na poli výzkumu vzdělanostních nerovností (instruktivně) uspořádat, demonstrovat kličové zlomy v poznání a ve vývoji měřicích nástrojů, jež jsou $\mathrm{k}$ tomuto poznání používány. Z perspektivy, kterou umožňuje časový odstup, se pokusíme ukázat, že empirický výzkum vzdělanostních nerovností je nezbytné považovat za svébytnou odnož sociálně stratifikačního výzkumu, který má svou historii, metodologii a vědecká zjištění. Pro úplnost je nutné podotknout, že soudobé empirické analýzy sociologie vzdělání se zaměřují pouze na měření a vysvětlování nerovností, přičemž otázkami spravedlnosti se $\mathrm{v}$ duchu Weberovy nehodnotící sociologie zabývají jen v náznacích a morální soudy přenechávají filozofưm [viz Rawls 2001; Nozick 1974; Hayek 1994; nejnověji pak např. Swift 2003]. Implicitně se rovněž pracuje se skutečností, že ne všechny nerovnosti jsou způsobeny socializací: jistá část nerovností ve vzdělání je způsobena rozdíly ve vrozené inteligenci [Fraser 1995]. Vztah IQ a dědičnosti však není pro sociologický výzkum vzdělanostních nerovností dominantním problémem, spíše faktorem, kterému je implicitně připisován blíže neurčený podíl. 


\section{První období empirického výzkumu vzdělanostních nerovností}

První období sociálně stratifikačního výzkumu vzdělanostních nerovností je možné vymezit šedesátými a sedmdesátými léty dvacátého století. Z hlediska věcného šlo $\mathrm{v}$ tomto období o identifikaci sociálních a ekonomických faktorů, které podmiňují dosažené vzdělání. Za všechny koncepce, které v tomto období vznikly [Jones 1971; Kerckhoff 1974; Treiman, Terrell 1975; Hauser 1972; Featherman, Hauser 1978], toto období nejvýstižněji charakterizují dva modely sociální stratifikace: Blau-Duncanův základní model sociální stratifikace a Sewell-Hauserův sociálně-psychologický model.

\subsection{Blau a Duncan - základní model sociální stratifikace}

V šedesátých letech 20. století došlo k průlomu ve výzkumu sociální stratifikace díky zásadnímu důrazu na vzdělání, se kterým přišli P. Blau a O. D. Duncan [1967]. Vyšli z předpokladu, že proces industrializace vedl ke zvýšení hodnoty vzdělání a kvalifikace pro výkon zaměstnání a snažili se empiricky vyřešit, nakolik sociální původ stále ovlivňuje dosažený zaměstnanecký status. Sledovali proto závislost mezi sociálním původem, vzděláním a začátkem kariéry a zkoumali jejich přímý a nepřímý vliv na zastávané zaměstnání. $V$ jejich pojetí by askriptivní faktory neměly mít vliv žádný, případně by se měl tento vliv jako historický relikt zmenšovat a postupně zcela zaniknout. Významným metodologickým průlomem jejich zkoumání bylo použití path analýzy, která autorům umožnila rozložit korelaci mezi zaměstnáním syna a zaměstnáním otce do dílčích příčinných souvislostí zprostředkovaných intervenujícími proměnnými (vzděláním otce, vzděláním syna a jeho př́ijmem). Základní otázky, které si Blau a Duncan položili, zněly: Jak a do jaké míry podmiňují okolnosti narození jedince jeho dosažený status? Jak status (jedno zda připsaný či získaný) v jedné fázi životního cyklu ovlivňuje vyhlídky na fázi následující? Jsou horší šance některých skupin lidí na získání dobrého zaměstnání způsobeny jejich horším vzděláním nebo jinými faktory?

Pro tento účel vyvinuli tzv. „základní" model determinace zaměstnaneckého statusu, sestávající z pěti základních standardizovaných proměnných: 1. dosažené vzdělání otce; 2 . status otcova povolání; 3 . dosažené vzdělání respondenta; 4. status respondentova prvního zaměstnání; 5 . status respondentova zaměstnání v roce 1962 (době šetření). Zatímco vzdělání bylo zařazeno do kategorie od 1 do 8 podle počtu let školní docházky, status povolání byl označen socioekonomickým indexem SEI v rozsahu od 0 do 96, který zkonstruoval Duncan [1961] takto: $\mathrm{SEI}=0,59^{*}$ př́ijem $+0,55^{*}$ vzdělání $-6,0$. Na teoretické úrovni totiž Duncan tvrdil, že povolání je činností spojující vzdělání a př́ijem. Pomocí této rovnice předpověděl socioekonomický status všech povolání své doby v USA a později z něj byl odvozen Mezinárodní index socioekonomického statusu povolání ISEI [Ganzeboom, De Graaf, Treiman 1992]. Metodou path analýzy a lineární regrese, tj. porovnáním koeficientů vyjadřujících vliv faktorů determinujících dosažené 
vzdělání a porovnáním korelací mezi standardizovanými proměnnými (otcovým vzděláním, jeho zaměstnaneckým statusem, respondentovým vzděláním, statusem jeho prvního a současného zaměstnání, ale i velikostí bydliště, rasou, počtem sourozencủ atd.), autoři zjistili klesající efekt i odhad relativní dủležitosti askriptivních faktorů (sociálního původu) ve všech věkových kohortách. ${ }^{2}$ Hlavní závěry autorů o dosahování zaměstnaneckého statusu byly tyto:

1. Status respondentova současného zaměstnání je silněji ovlivněn nabytým vzděláním než jeho prvním zaměstnáním.

2. Vzdělání jedince je mnohem důležitěǰším vlivem (přímým i nepřímým) působícím na dosažené zaměstnání než zaměstnání otce.

3. Vliv vzdělání na konečnou zaměstnaneckou pozici v posledních desetiletích vzrostl. Korelace mezi vzděláním a zaměstnaneckým statusem je významně vyšší pro respondenty než pro jejich otce ve všech zkoumaných věkových kohortách.

4. Zaměstnanecký status syna závisí přímo na stupni jeho vzdělání a na otcově zaměstnaneckém statusu, ale jen nepřímo na otcově dosaženém vzdělání.

5. Př́ijem respondenta závisí přímo na statusu jeho zaměstnání a dosaženém vzdělání, ale jen nepřímo na otcově vzdělanostním a zaměstnaneckém statusu.

Blau-Duncanův model vysvětlil přesto jen velmi malou část závisle proměnné (respondentova zaměstnání), což však pro autory neznamenalo negativní výsledek. Sami píší: „Sociologové si zřídka uvědomují, co by znamenalo žít ve společnosti, kde by téměř dokonalé vysvětlení závisle proměnné bylo dosaženo studiem příčinných proměnných, jako např. zaměstnáním otce nebo vzděláním respondenta. $\mathrm{V}$ takové společnosti by bylo samožrejmě pravda, že někteří jsou odsouzeni $k$ chudobě téměř od narození ... kvůli ekonomickému statusu či povolání rodičů. Jiní by zase byli předurčeni k blahobytu (bohatství) či ke slušným poměrům. Nikoli vlastním úsilím, ale majetkem by měnili směr osudu..." [Blau, Duncan 1967: 174]. O problematice zvýhodnění či znevýhodnění rodinným původem tvrdí: „Kdyby rodiče, kteří dosáhli určitého sociálního statusu, nemohli tento využít k získání srovnatelného statusu pro své děti, mohli bychom skutečně mít ,rovné příležitosti'. Ale nemohli bychom mít rodinný systém - přinejmenším ne v dnešním smyslu slova. A tento moment nebyl nepochopen ani v radikálních, zejména marxistických, ideologiích“ [Blau, Duncan 1967: 205].

Blau a Duncan tedy celkově doložili jak historicky rostoucí průměrnou úroveň vzdělání (na úroveň stř̌ední školy), tak klesající vzdělanostní nerovnosti (ovšem v pojetí distribučním, tj. dle rostoucího počtu vzdělaných jedinců bez ohledu na to, z jakých vrstev pochází). Problém jejich způsobu empirického ověřování spočíval jak $\mathrm{v}$ tom, že vzdělání $\mathrm{v}$ něm vystupovalo $\mathrm{v}$ podobě nakumulovaných roků školní docházky, tak především $\mathrm{v}$ tom, že používali metodu lineární regrese neschopnou odhalit změny v alokaci vzdělání (ti. sociální původ

${ }^{2}$ Grafické znázornění těchto vztahů zprostředkovává Matějů [2005]. 
absolventů škol). Realita byla totiž taková, že jimi zjištěný pokles vlivu sociálního původu na stupeň dosaženého vzdělání jedince byl sice způsoben růstem vzdělanostních př́iležitostí, hlavně však změnou principů v alokaci vzdělání.

\subsection{Sewell a Hauser - sociálně-psychologický model}

Zatímco Duncan se snažil svůj model dále zdokonalovat (na tzv. rozšířený model), nap̌r. o proměnnou inteligence, př́jem či počet sourozenců [Duncan 1968; Duncan, Featherman, Duncan 1972], jak již napovídá sám název modelu sociálně-psychologického, jeho stěžejní invence spočívala v zahrnutí sociálně-psychologických charakteristik do základního modelu Blau-Duncanova (tj. aspirací, motivací, hodnot, vlivu primárních skupin apod.). Počátky tohoto přístupu spadají do stejné doby, kdy byl publikován zmíněný model základní. Autoři modelu sociálně-psychologického ani tak nepolemizovali s pohledem na školní systém jakožto selektivní a třídící mechanismus vycházející ze schopností žáků, avšak upozorňovali na jeho limity a doplnili ho o další podstatné charakteristiky. Sewell a Shah [1967] a poté Sewell, Haller, Portes [1969] upozornili jednak na nedostupnost vzdělávání stejné kvality pro všechny, což následně ovlivňuje i možnosti pro další vzdělávací dráhu, jednak především na roli aspirací, kultivovanou zejména ve výchozí rodině. Podstatou sociálně-psychologického modelu byla snaha zachytit takový model reality, který by vysvětlil zejména velikost a roli třídních rozdílů $\mathrm{v}$ aspiracích (tj. jejich sociální podmíněnost), protože jejich značná část zůstávala nevysvětlena.

Tímto modelem byl mimo jiné odhalen přímý vliv schopností jedince (její/ jeho IQ) na sílu vlivu významného okolí, což verifikovala i další, upravená verze modelu [Sewell, Haller, Ohlendorf 1970]. V ní se však podařilo odkrýt i přímé efekty školního úspěchu na vzdělanostní aspirace a dosažené vzdělání. Obecně řečeno, po obsahové stránce se modelem podařilo prokázat, že vzdělanostní a zaměstnanecká kariéra je sice ovlivněna sociálním původem a mentálními schopnostmi (což ukázal již model Blau-Duncanův), ale že tento vliv je zprostředkován mechanismy sociálně-psychologickými. Bližší popis vstupních hypotéz sociálně-psychologického modelu i výsledky jejich ověřování, stejně jako vývoj tohoto modelu jsou popsány v Matějů [2005], proto by bylo duplicitní je zde uvádět. Zájemci o tuto problematiku se v uvedeném textu seznámí rovněž s metodologickým zdokonalováním modelu, známým pod pojmem „Wisconsinský model“. Tento metodologicky a později i obsahově revidovaný sociálně-psychologický model [Sewell, Hauser 1972; Hauser, Tsai, Sewell 1983] se vypořádal jednak s problémem definice latentních proměnných, jednak s kontrolou nad chybami měření hlavních proměnných a korelace mezi nimi. Základním závěrem bylo zjištění, že vzdělanostní systém v tehdejších USA je otevřený a přispívá ke snižování nerovností. 


\section{Druhé období empirického výzkumu vzdělanostních nerovností}

Druhé období empirického výzkumu vzdělanostních nerovností lokalizujeme do osmdesátých let minulého století. Koncepce, které v tomto období vznikají, jsou reakcí na metodologické a obsahové limity konceptů prvního období, přitom však zužitkovávají významné metodologicko-statistické posuny, k nimž ve druhé polovině sedmdesátých let na poli sociální vědy došlo [srov. Bishop, Fienberg, Holland 1975]. Toto období charakterizujeme dvěma hlavními koncepty: alokací vzdělání a maximálně udržovanou nerovností (MMI) ve vzdělání.

\subsection{Koncept alokace vzdělání Roberta Marea}

Nevýhodou prací spadajících do prvního období bylo použití lineárního regresního modelu determinace nejvyššího dosaženého vzdělání (tj. závislou proměnnou bylo nejvyšší dosažené vzdělání respondenta) a neznalost konceptu relativních šancí v přístupu ke vzdělání. Průlomem byla v tomto ohledu až práce R. Marea [Mare 1980, 1981] a jeho inovativního „tranzitivního“ př́istupu. R. Mareovi se podařilo teoreticky i metodologicky oddělit dvě odlišná pojetí vzdělanostních nerovností: nerovnosti v distribuci vzdělání (tj. disperzi v distribuci formálního vzdělání) a relativní šance potomků různých sociálních tříd na dosažení určitého stupně vzdělání (tzv. alokaci vzdělání). Jak jsme již vysvětlili výše, v metodologii výzkumu vzdělanostních nerovností se mělo dlouho za to, že právě zvyšující se podíl lidí, kteří dosahují stále vyšších stupňů vzdělání, indikuje klesající vzdělanostní nerovnosti [Blau, Duncan 1967; Featherman, Hauser 1978]. Mare [1981] však přišel s novým konceptem: jeho tzv. tranzitivní model odhaluje vliv sociálního původu na přechod (tranzici) z určitého stupně vzdělávacího procesu na stupeň následný. Je totiž zřejmé, že každý přechod je jinak důležitý, a proto na nich působí sociální původ s nestejnou intenzitou. V Mareově pojetí může být prostřednictvím logistického modelu determinace pokračování ve studiu dosažení určité úrovně vzdělání měřeno sadou pravděpodobností, které vyjadřují šance, že individuum bude pokračovat ve studiu až na tuto úroveň, ovšem pouze za předpokladu, že absolvoval úroveň předcházející. Takové rozčlenění vzdělávacího procesu na stupně oddělené jednotlivými přechody umožňuje analýzu trendů a odlišností na jednotlivých úrovních bez ovlionění celkovou proporcí jedinců, kteří pokračují z jedné úrovně na druhou.

Podle Marea by modely analyzující změny ve vzdělanostních nerovnostech měly být specifikovány s ohledem na ten ze dvou výše uvedených konceptů, který chtějí vysvětlit (tj. distribuci či alokaci vzdělání). Ve vztahu ke zjištěním Blaua a Duncana to znamená, jak dokázal Mare, že vliv sociálního původu na nejvyšší dosažené vzdělání může sice díky růstu vzdělanostních příležitostí skutečně klesat (tj. nahlížíme-li vzdělanostní nerovnosti optikou distribuce vzdělání), ale zároveň se efekt sociálního původu na šanci úspěšného překonání přechodu mezi jednotlivými stupni vzdělání měnit nemusí, nebo může dokonce růst. Mareova 
koncepce tranzitivních přechodů se proto stala standardním analytickým nástrojem zkoumání vzdělanostních nerovností v současné sociologii [Shavit, Blossfeld 1993].

Mare [1993] však rovněž upozornil na zranitelnost (a koneckonců i meze) dosavadního způsobu měření vlivu sociálního původu na vzdělanostní trajektorii jedince. Snažil se tímto směrem dále rozpracovat svou koncepci tranzitivních přechodů, protože právě nepozorovaná heterogenita („unmeasured heterogeneity") má za následek nižší naměřené efekty sociálního původu na pozdějších tranzicích. Zkoumáme-li tedy šance jedince na úspěšný přechod mezi dvěma úrovněmi vzdělávacího systému, je nám jasné, že jsou determinovány nejen nezávislými proměnnými, které jsme zařadili do vyextrahovaného modelu reality, ale i takovými faktory, o kterých jako analytici nevíme nebo které nelze měřit. Tyto neměřené determinanty vzdělání (ambice, motivace, aspirace, ale i inteligence) nám mohou podle Marea změnit velikost napozorovaných efektů rodinného původu, a také způsob, jakým si vysvětlíme realizaci těchto efektů. To, co pak následně připíšeme rozdílům v procesu získávání vzdělání, způsobila ve skutečnosti tzv. nepozorovaná heterogenita („,unobserved heterogeneity“). Mare ukázal pomocí několika modelů, jak velký může být vliv heterogenity a jak lze např. pomocí sourozeneckých údajů zlepšit odhady, které jinak působení heterogenity ignorují. Sourozenci totiž zpravidla "nepozorovanou heterogenitu“ sdílejí.

Vzhledem k omezením daným dostupnými soubory dat obsahujícími zpravidla neúplné údaje o rodinném zázemí respondenta je však Mareho „,sourozenecké“ řešení multikauzality obtížně aplikovatelné. Vliv sociálního původu v procesu dosahování vzdělání jedince je tak stále zkoumán především přes dokončené vzdělání otce a jeho socioekonomický status (vedle dalších individuálních charakteristik, jako je pohlaví, počet sourozenců, velikost bydliště apod.).

\subsection{Maximálně udržovaná neroonost - Raftery a Hout}

Raftery a Hout [1993] si stanovili několik hypotéz, které jako celek nazvali „,maximally maintained inequality“ (MMI). Podle MMI jsou třídní bariéry v dostupnosti vzdělání funkcí nabídky a poptávky, a to na každé úrovni vzdělávacího systému. Autoři vyšli ze skutečnosti, že ačkoli bylo v r. 1967 v Irsku odstraněno školné a zavedeny byly také další rovnostářské reformy, efekt sociálního původu na zkoumané tranzice se $\mathrm{v}$ letech 1921 až 1975 mezikohortně nezměnil, pouze se snížily celkové rozdíly $\mathrm{v}$ dosaženém vzdělání mezi jednotlivými třídami. Tyto reformy tedy neměly žádný vliv na rovnost vzdělanostních př́ležitostí - odstranění školného samo o sobě př́iliš nezměnilo vzdělanostní nerovnosti. Došlo jen ke slabému nárůstu podílu synů navštěvujících výběrové střední školy, ovšem ze všech sociálních tříd, čímž se primárně vyšlo vstříc potomkům rychle rostoucí britské střední třídy. Odstranění školného tak bylo spíše větrem do plachet těm rodinám, které by daly své děti studovat za jakýchkoli okolností, ovšem nezlepšilo př́istup ke střednímu vzdělání dětem z méně prúínivého sociálního prostředí. 
Co tedy MMI znamená? Říká, že podíly studenti̊, kteří prošli tranzicí, a poměry šancí („,odds ratios“) mezi studenty s různým sociálním původem na daném vzdělanostním přechodu zůstávají mezikohortně stejné až do momentu, kdy jsou nucené se změnit kvůli rostoucímu počtu přijatých studentů. Toto platí: 1. Za předpokladu, že dochází k populačnímu nárưstu a přirozenému zvyšování životní úrovně (sociálního původu), protože z tohoto důvodu se zvyšuje podíl přijatých na střední a vysoké školy. Pak se podíly těch, kteří projdou příslušnými tranzicemi, v závislosti na sociálním původu nemění. 2. Když expanze zvyšuje počet přijatých rychleji, než roste sama poptávka. Tehdy dochází $\mathrm{k}$ redistribuci studijních míst mezi uchazeče různého sociálního původu a podíly těch, kteří prošli tranzicí a pocházejí ze všech sociálních tříd, se zvyšují, ale tak, aby třídní „,odds ratios“ zůstaly zachovány. 3. Je-li poptávka po daném stupni vzdělání uspokojena od nejvyšších sociálních tříd, tj. jestliže podíl úspěšných (angl. „transition rate") se v případě nejvyšších sociálních tříd blíží $100 \%$. Pak se poměry šancí snižují - asociace mezi sociálním původem a dosaženým vzděláním slábne. Zároveň platí, že výsledná nižší nerovnost ve vzdělanostních příležitostech se objevuje pouze tehdy, pokud expanze není vyvážena jinak.

Toto vše tedy znamená, že MMI je naplněna tehdy, když: 1) vyšší sociální třídy dosahují vyšší úspěšnosti v přechodu na vyšší vzdělanostní stupně; 2) celková míra participace na vzdělávání se nesnižuje; 3) zaměstnanecká strukturní mobilita upřednostňuje povolání s vyšší prestiží či s vyšším statusem. Důležitým zjištěním je tvrzení, že podíly těch, kteří projdou tranzicemi i nerovnost mezi nimi (měřeno „odds ratios“), zůstanou konstantní, pokud na jejich změnu nebude pưsobit nárůst podílu přijatých studentů. $S$ tím souvisí další dủležitý závěr, a sice že vzdělanostní dimenze sociálního původu působí nejsilněji na přechodu mezi základní a střední školou, slabší je př̀i dokončení střední školy a není signifikantní na přechodu mezi střední a vysokou školou, tj. vliv třídy je nejsilnější na prvních tranzicích. Ve světle tohoto shrnutí je pak snadné si dovodit, že expanze sekundárního vzdělání po 2 . světové válce v Irsku snížila třídní rozdíly nikoli proto, že by tř́ída ztratila svưj vliv při vstupu na střední školu, ale proto, že proces výběru studentů přestal být tak selektivní. $V$ neposlední řadě je třeba zmínit, že ačkoli MMI byla vystavěna na výsledcích analýzy irských dat, její aplikace na dalších minimálně 13 zemích ukázala, že její platnost je s velkou pravděpodobností mnohem obecnější [Shavit, Blossfeld 1993].

\section{Třetí období empirického výzkumu vzdělanostních nerovností}

Třetí období výzkumu vzdělanostních nerovností není zatím uzavřené. Jeho počátek spatřujeme na počátku první dekády jedenadvacátého století. Stejně jako v předchozím případě, koncepce, které v této době vznikly, jsou reakcí na nedostatky a limity koncepcí druhého období. Nejvýznamnějšími představiteli třetího období jsou multinomiální tranzitivní model a model nerovnosti udržované ve výsledku (EMI). 


\subsection{Multinomiální tranzitioní model - Breen a Jonsson}

Jak jsme popsali výše, z Mareho koncepce vyplynulo, jak silně by mohlo být zavádějící soustředit svou pozornost pouze na výsledný (dosažený) stupeň vzdělání a ignorovat různý vliv sociálního původu na dílčích stupních vzdělávacího systému, kterými student prochází [Mare 1981]. Breen a Jonsson [Breen, Jonsson 2000] však př̌šli se zásadní inovací Mareho tranzitivního modelu. Zohlednili v ní skutečnost, že vzdělávací systémy často obsahují i paralelní typy studia na formálně stejné úrovni vzdělávání (u nás jsou to např. gymnaziální, střední odborná a učňovská studia s maturitou, která všechna umožňují přechod na vysokou školu). Implicitním předpokladem Mareho modelu je totiž unilinearita průchodu vzdělávacím systémem. Breen a Jonsson poukázali na fakt, že všechna individua neprochází stejnou trajektorií, ale že existují paralelní studijní dráhy, které se liší svým zaměřením (př. odborné či akademické). $V$ konečném důsledku tak determinují pravděpodobnost úspěchu na následných přechodech, kde se absolventi formálně stejné úrovně vzdělání nemusí vůbec sejít.

Breen a Jonsson proto nahradili Mareho logistický model modelem multinomiálním, který bere $\mathrm{v}$ potaz typ předchozí trajektorie. Podle zjištění Breena a Jonssona ovlivňuje cesta, kterou si student zvolil při průchodu školním systémem (tj. typ absolvovaných škol), pravděpodobnost úspěchu v dalších tranzicích, včetně pravděpodobnosti dokončení započaté školy. Podle autorů je multinomiální model robustní také při zjištování nepozorované heterogenity („,unmeasured heterogeneity“). Pomocí svého modelu zjistili, že efekty třídního původu na pravděpodobnost úspěchu v první tranzici (přechod ze základní na střední školu) a druhé tranzici (dokončení střední školy) jsou vyšší, než ukázal Mare, a v přechodu na terciální stupeň vzdělání jsou tyto efekty podle nich naopak nižší.

\section{2. Nerovnost udržovaná ve výsledku - Samuel Lucas}

Samuel Lucas svou teorií nazvanou „effectively maintained inequality“ (EMI) reagoval na teorii MMI a kritizoval její předpoklad, že nerovnosti na určité úrovni vzdělání jsou za situace univerzálního přístupu nulové. Zdůraznil kvalitativní rozdíly na té samé úrovni vzdělání (on sám se zaměřil především na terciární úroveň vzdělávání), způsobené selekcí do různých typů škol. V tomto ohledu může jeho teorie připomínat Breen-Jonssonovu kritiku Mareova předpokladu unilineárního průchodu vzdělávacím systémem. Ačkoli Lucasova výtka je platná pro každou úroveň vzdělávacího systému, aktuální je především jakožto varování před přehlížením doprovodného negativního důsledku expanze vysokoškolského vzdělání (jeho tzv. masifikace). I po dosažení saturace na tomto stupni vzdělávání totiž vcelku vážně hrozí, že nerovnosti v šancích na jeho dosažení jsou (budou) vystřídány nerovnostmi v šancích na studium na "kvalitnějších“ univerzitách. Tzv. diferenciace vzdělanostních drah, která doprovází vzdělanostní expanzi, tak sice na jedné straně přispívá k větší účasti jedinců pocházejících 
z nižších vrstev, ovšem přináší s sebou i reálné nebezpečí, že tyto osoby budou mít př́istup pouze do méně kvalitních škol, tj. diferenciace se změní v diverzifikaci [Brint, Karabel 1989].

Diferenciace s sebou totiž přináší nejen rozdíly v prestiži, selektivitě i materiálních zdrojích jednotlivých škol, ale v zemích s binárním systémem univerzitního vzdělávání (tij. studiem končícím bud' titulem Bc., či studiem pokračujícím až k završení titulem Mgr.) a placením školného s sebou nese i vyšší studijní náklady, tedy i relativně větší ztráty pro potomky nižších sociálních vrstev v případě jejich studijního neúspěchu. Lucas tvrdí, že studenti při svém rozhodování, zda pokračovat, či nepokračovat dále ve svém vzdělávání na vyšších stupních, berou v potaz zejména svůj poslední nejlepší výkon. Pak je třeba se vrátit k tomu, co ř́ká teorie racionální volby [Goldthorpe 1996; Breen, Goldthorpe 1997] i teorie MMI, a sice, že studenti a jejich rodiny se o pokračování ve studiu rozhodují na základě poměřování nákladů a výnosů, které se s ním pojí. Skutečný náklad (v jednotkách užitku) je větší pro rodiny, které mají nižší příjmy a naopak. Lucas tak polemizuje se závěrem, ke kterému došel Mare i autoři teorie MMI, a sice že při vstupu na vyšší stupně vzdělání a při saturaci blížící se $100 \%$ vliv sociálního původu klesá. Dle Lucase nestačí pouze konstatovat, zda je vstup na danou úroveň vzdělávání kvantitationě univerzální, ale je třeba se rovněž zabývat otázkou, jaká je v závislosti na sociálním původu dostupnost kvalitativně srovnatelné úrovně.

EMI se tedy snaží spojit model po sobě jdoucích rozhodnutí s tím, kde se respondenti v rámci vzdělanostní stratifikace o přechod pokouší, tj. zkoumá pohyb studentů $\mathrm{v}$ rámci stratifikované vzdělanostní dráhy. S MMI se rozchází díky zohlednění skutečnosti, že ještě před vstupem na vysokou školu se rozhodnutí o další dráze, učiněné v posledním ročníku studia, liší v závislosti na sociálním původu. Rozhodnutí učiněná na nižších tranzicích totiž „zředi“" skutečný vliv sociálního původu na tranzicích vyšších. Vybere-li si potomek nižších vrstev na základě poměřování nákladů a výnosů „horši“" střední školu, která je pro další život "praktičtější", je pak nejen pravděpodobnější, že při přechodu na školu vysokou nebude úspěšný, ale že i vliv sociálního původu na danou tranzici bude nižší, a to zejména proto, že se o takový přechod vủbec nepokusí. EMI se tedy snaží spojit dva dominantní proudy výzkumu vzdělanostních nerovností: 1) výzkum vzdělanostních přechodů (angl. „educational transitions research“), který říká, že vliv sociálního původu klesá směrem k vyšším tranzicím. V rámci tohoto názorového proudu pak existují dva směry, které se snaží vysvětlit, proč platí, že čím pozdější je tranzice, tím menší je vliv sociálního původu na ní: a) LCP (life-course changes), který tvrdí, že jak se vztah rodičů a dětí s jejich dospíváním mění, slábne i vliv rodičù na rozhodování dětí o pokračování ve vzdělávání; b) MMI. 2) Druhým dominantním názorovým proudem pak je výzkum vzdělávacích drah (angl. education tracking research), který klade důraz na kvalitativní větvení vzdělanostního systému. Jak již bylo řečeno výše, EMI se snaží o konvergenci obou těchto dominantních názorových proudư výzkumu vzdělanostních nerovností [Lucas 2001]. 


\section{Tři období výzkumu vzdělanostních nerovností z hlediska metodologického}

Od počátků sociálně stratifikačního výzkumu v padesátých letech minulého století je zřejmé, že nelze mechanicky srovnávat rodiče a jejich potomky, a na základě prostého rozdílu mezi nimi vypovídat o velikosti či proměně vzdělanostních nerovností. Vzdělanostní struktura se mění (především díky státním zásahům a opatřením) a s ní se mění i velikost vzdělanostních nerovností. Na základě jednoduchého srovnání rodičů a potomků lze identifikovat strukturní (někdy také vynucené) změny ve vzdělání, které $\mathrm{v}$ tomto srovnání nicméně koexistují $\mathrm{s}$ čistými šancemi či př́iležitostmi na dosažení vzdělání, a to především s ohledem na sociální původ potomka. Po dlouhou dobu bylo velkou výzvou řady sociálně stratifikačních badatelů na poli vzdělanostních nerovností v takovém srovnání rodičů a jejich potomků separovat strukturní změny od změn čistých. Neboli odpovědět na otázku, jak moc je zjištěná nerovnost ve vzdělání efektem strukturních změn ve vzdělávacím systému, a jak moc je odrazem rovnosti vzdělanostních př́ležitostí.

Blau a Duncan [Blau, Duncan 1967], jakožto reprezentanti prvního období analýzy vzdělanostních nerovností, na toto odlišení v základním stratifikačním modelu rezignovali. Ukázali, že rozdíl mezi vzděláním otce a jeho potomka nekoresponduje a nikdy nemůže korespondovat se strukturními vzdělanostními posuny, protože otcové bud' nereprezentují generaci otců, nebo jsou odvozeni od potomků, kteří jsou předmětem měření [srov. také Duncan 1964]. Rozdílný věk potomků v době šetření totiž znemožňuje identifikovat jednu generaci otců. Dále otcové, kteří neměli potomka a přitom tvoří generaci rodičů, jsou z šetření vynecháni a naopak otcové, kteří mají potomků více, by měli být díky nim v šetření nadreprezentováni. Nejzávažnější výhrada ovšem spočívá v přenosu reprezentativity, který prosté srovnání rodiču a dětí z hlediska vzdělání předpokládá. Soubor potomků je reprezentativní $\mathrm{v}$ čase sběru dat, nicméně soubor jejich otců nikoliv - nereprezentuje jednu generaci. Duncan a Blau [Blau, Duncan 1967] proto navrhují zabývat se vzdělanostními nerovnostmi v čase sběru dat (v analýze se vystř́íhat retrospektivního pohledu) a sociální původ a vzdělání otce pojímat jako proměnnou, která ovlivňuje dosažené vzdělání potomka.

Z hlediska metodologie to znamená analýzu vzdělanostních nerovností pomocí lineárně regresního modelu, který se stává základem pěšinkové analýzy („path analysis“) [Duncan 1966a; Duncan 1966b]. Podstatou této analýzy je zkoumat efekt vybraných faktorů ovlivňujících nejen dosažené vzdělání, ale také zaměstnaneckou pozici, a především pak vztah mezi nimi (při kontrole ostatních faktorů). Proměnné jsou v tomto př́stupu pojímány jako kardinální (dosažení vzdělání je indikováno počtem let strávených ve škole). Otázky, na něž je tento př́stup schopen odpovědět, mají následující podobu: Jaký je efekt vzdělání otce na vzdělání syna? Jak moc dosažené vzdělání souvisí se sociálním původem? Jak moc vzdělání zprostředkovává vztah mezi zaměstnáním otce (sociálním původem potomka) a jeho současným zaměstnáním? 
Pěšinková analýza byla později rozpracována do metod strukturního modelování [Jöreskog 1970; Duncan 1975; Bielby, Hauser 1977] a rozšiřuje se také do jiných oblastí sociálněvědního výzkumu. Používání obou těchto technik je nicméně pevně svázáno především se šedesátými a sedmdesátými lety minulého století. Zejména kvůli pojímání jednotlivých proměnných jako kontinuálních (kardinálních) byly postupně tyto techniky opuštěny. I když tento přístup umožňoval vyjádřit vztahy mezi proměnnými pomocí několika málo parametrů, argumenty, že proměnné v sociálním světě nejsou svou povahou kardinální (nesplňují tedy požadavky normálního rozložení a nelze je vyjádřit pomocí aritmetického průměru, směrodatné odchylky a korelačního koeficientu), postupně převládly a pěšinková analýza a metody strukturního modelování v průběhu osmdesátých a devadesátých let dvacátého století přestávají být ve výzkumu vzdělanostních nerovností používány.

Druhé období sociálně stratifikačního výzkumu vzdělanostních nerovností je z hlediska metodologického spojeno se sekvenčním modelem logistické regrese vzdělanostních tranzicí. Na začátku osmdesátých let Robert Mare publikuje text [Mare 1980], v němž dosažené vzdělání již není pojímáno jako spojitá proměnná a není indikováno počtem let strávených ve škole. Jedná se o holý fakt, zda dané vzdělání existuje, nebo nikoliv. Strukturní efekty na vzdělanostní nerovnosti jsou očištěny prostřednictvím transformací efektư na jejich šance a poměry mezi nimi. ${ }^{3} \mathrm{~V}$ modelu je navíc zohledněna posloupnost vzdělanostních stupňu (to, že nižší vzdělanostní stupeň je vždy předpokladem vyššího vzdělanostního stupně). Dosažené vzdělání je proto definováno jako sled přechodů (tranzicí) z jednoho vzdělanostního stupně do jiného. Cílem takového přístupu je modelovat efekty jednotlivých vysvětlujících proměnných na šanci být úspěšný právě v těchto tranzicích mezi vzdělanostními stupni. Na každém vzdělanostním stupni je jiný typ žáků a jiná povaha jejich selekce, což je předpokladem tohoto modelu. Navíc je model vhodný pro kohortní srovnání šancí na jednotlivé tranzice. Lze jej do jisté míry použít jako indikátor proměny vzdělanostních nerovností v čase [Mare 1980; Müller, Karle 1993; Shavit, Blossfeld 1993].

Aplikace sekvenčního modelu logistické regrese vzdělanostních tranzicí v průběhu devadesátých let minulého století poukázala na několik jeho limitů.

\footnotetext{
${ }^{3}$ V sociálně stratifikačním výzkumu jsou šance a poměry mezi nimi považovány za nástroj měření nerovností $\mathrm{v}$ přístupu do jednotlivých třídních pozic podle třídního původu jedinců. Ve výzkumu vzdělanostních nerovností jsou (podobně) poměry šancí považovány za indikátor měření nerovností v přístupu do jednotlivých vzdělanostních stupňủ s ohledem na výchozí třídní pozici. Dủležitou vlastností poměrů šancí je - jak ukazují matematické důkazy -, že jejich velikost neovlivňují marginální tabulkové četnosti, ani celkový počet respondentů [Powers, Xie 2000]. Z tohoto důvodu se má za to, že tato míra není ovlivněná strukturními změnami. Dnes ovšem někteří autoři tuto vlastnost poměrů šancí zpochybňují [srov. Swift 2004; Ringen 2000; Hellevik 2007]. Argumenty, o něž se představitelé těchto názorů opírají, nejsou ovšem zatím natolik přesvědčivé, aby poměry šancí jako základ analýzy nerovných šancí (at' už třídních, nebo vzdělanostních) přestaly dominovat empiricky orientovanému sociálnímu výzkumu.
} 
Prvním z nich je předpoklad tohoto modelu, že jedinci procházejí vzdělanostním systémem stejným způsobem a pouze z nižšího do vyššího stupně. Kritikové modelu [Breen, Jonsson 2000; Lucas 2001] ovšem upozorňují na skutečnost, že mnoho evropských vzdělávacích systémů obsahuje paralelní větve, které jsou kvalitativně odlišné. Prostupnost mezi nimi je rovněž rozdílná. Především ale poskytují rozdílné šance na pokračování $\mathrm{v}$ dalších stupních vzdělávacího systému. Rozdílnost šancí, danou např́klad rozdílem mezi učebním oborem a gymnáziem, je obtížné zohlednit $\mathrm{v}$ sekvenčním modelu logistické regrese. $\mathrm{Z}$ tohoto důvodu Breen a Jonsson [Breen, Jonsson 2000] na konci devadesátých let minulého století navrhují jako alternativu pro analýzu vzdělanostních nerovností multinomiální model vzdělanostních tranzicí.

Druhým limitem sekvenčního modelu logistické regrese je to, že efekty jednotlivých proměnných, které jsou v rámci modelu identifikovány, mohou být výsledkem nepozorované (neměřené) proměnné. Otázkou je, nakolik daný model popisuje skutečné efekty a nakolik popisuje efekty, které jsou zkreslené dalšími nepozorovanými proměnnými [Lucas 1996]. $V$ tomto ohledu se diskutuje především o přímo úměrně klesajícím efektu sociálního původu na jednotlivých, po sobě jdoucích tranzicích. Řešení tohoto problému navrhl v nedávné době Lucas [2001]. Ukázal, že přístup ke vzdělání z hlediska tranzicí je adekvátním a oprávněným př́ístupem, nicméně v modelu musí být zohledněny jako vysvětlující proměnné šancí na jednotlivé tranzice i takové proměnné, které nejsou - podobně jako závisle proměnná - neměnné v čase. Jak multinomiální model vzdělanostních tranzicí [Breen, Jonsson 2000], tak zohlednění časové variability vysvětlujících proměnných $\mathrm{v}$ sekvenčním modelu lze považovat $\mathrm{z}$ hlediska metodologického a statistického za zlom mezi druhou a zatím ještě ne plně konsolidovanou třetí generací sociálně stratifikačního výzkumu vzdělanostních nerovností.

\section{Závěr}

Nerovnosti v přístupu ke vzdělání představují sociální jev, o jehož působení (téměř) každý ví a které se (téměř) každá společnost snaží omezit na minimum. Způsob jejich měření prošel značným vývojem a je ovlivněn snahou mnoha badatelů o nalezení co nejdokonalejších analytických nástrojů. $V$ historii dosavadních empirických koncepcí výzkumu vzdělanostních nerovností je podle našeho názoru možné vymezit tři zásadní inovace metodologické (základní model stratifikačního procesu, koncept alokace vzdělání a multinomiální tranzitivní model) a tři zásadní inovace interpretační, ovšem úzce spjaté s vývojem kvantitativních metod používaných $\mathrm{v}$ analýze vzdělanostních nerovností (model sociálně-psychologický, MMI a EMI). V tomto textu jsme se snažili tyto interpretačně-metodologické inovace ve zkoumání vzdělanostních nerovností instruktivně uspořádat. Navrhli jsme proto rozlišovat tři stěžejní období, která podle nás ohraničují tři nejdůležitější etapy dosavadního vývoje empirických uchopení této problematiky. 
Třetí, poslední období, není podle našeho názoru stále ještě uzavřeno. Je založeno na snaze rozlišovat rozdílné úrovně kvality vzdělávání v různých vzdělávacích větvích, což umožnila metoda multinomiálního modelu vzdělanostních přechodů. Nejnovější diskuse se však odvíjí od popření samotného jejího matematického základu - argumentace některých vědců stojí na tvrzení, že dosavadní předpoklad spojovaný s poměry šancí, které jsou výstupem této metody, tj. jejich necitlivost vưči proměnám marginálních četností, je ve skutečnosti nepodložený. Diskuse na toto téma proběhla např. na jarním zasedání sekce RC28 Mezinárodní sociologické asociace (ISA), která proběhla v roce 2007 v Brně, nevedla však k názorovému konsenzu. Na jejím základě vznikla stat́ publikovaná na stránkách Czech Sociological Review [Hellevik 2007] shrnující protiargumenty vůči insenzitivitě poměrů šancí ke strukturálním početním změnám. O půl roku dříve tamtéž vyšla stat' jednoho z iniciátorů zmíněné diskuse, založená na téže argumentaci [Ringen 2006]. Autoři těchto statí tvrdí, že dlouhodobě publikované výsledky o stabilitě, at' již sociálních, či vzdělanostních, nerovností nemají ve skutečnosti opodstatnění. Protože se jedná o relativně odvážné zpochybnění veškeré v současné době použivané metodologie výzkumu sociálních a vzdělanostních nerovností, nelze než se těšit na to, jakým směrem se výzkum sociální stratifikace v budoucnosti vydá.

Natalie SimOnOvá je vědeckou pracovnicí v oddělení Sociologie vzdělání a stratifikace Sociologického ústavu $A V \stackrel{C}{R}$, v.v.i. Zabývá se výzkumem vzdělanostních nerovností v České republice i v mezinárodním srovnání, jejich vývojem, zdroji a procesy utvárení. $V$ poslední době se zaměruje zejména na vývoj vzdělanostní mobility v ČR. K jejím hlavním publikacím patři stati $v$ British Journal of Sociology of Education, Sociologickém časopise / Czech Sociological Review, Sociológii, nejnověji pak v The Sociological Review a rovněž kapitoly v několika domácích a zahraničních monografiích. Je dále editorkou knihy České vysoké školství na křižovatce (Sociologický ústav 2005).

TOMÁš KATRŇÁK je odborným asistentem na Fakultě sociálních studii Masarykovy univerzity v Brně. Zabývá se sociální stratifikací, třídní analýzou, sociální a vzdělanostní mobilitou, sociální statistikou a metodami zpracování sociologických dat (především analýzou kategorizovaných dat). Je autorem monografie Odsouzeni k manuální práci: Vzdělanostní reprodukce v dělnické rodině (Praha: Sociologické nakladatelství 2004), studie Třídní analýza a sociální mobilita (Brno: CDK 2005) a monografie Spříznění volbou? Homogamie a heterogamie manželských párů v České republice (Praha: Sociologické nakladatelství 2008). Publikoval v Sociologickém časopise, Sociologii, Demografii, East Central Europe $a$ European Sociological Review. 


\section{Literatura}

Althusser, L. 1971. „Ideology and Ideological Apparatuses (Notes towards an Investigation)." Pp. 127-187 in Lenin and Philosophy and Other Essays. New York, London: Monthly Review.

Bernstein, B. 1975. Class, Codes, and Control. London: Routledge.

Bielby, W. T., R. M. Hauser. 1977. „Structural Equation Models.“ American Review of Sociology 3: 137-161.

Bishop, Y. M. M., S. E. Fienberg, P. W. Holland. 1975. Discrete Multivariate Analysis: Theory and Practice. Cambridge: MIT Press.

Blau, P. M., O. D. Duncan. 1967. The American Occupational Structure. New York, London, Sydney: John Wiley \& Sons.

Bourdieu, P. 1973. „Cultural Reproduction and Social Reproduction.“ Pp. 71-112 in R. Brown (ed.). Knowledge, Education and Cultural Change. London: Tavistock.

Bourdieu, P., J. C. Passeron. 1964. Les Héritiers. Les étudiants et la culture. Paris: Les éditions de minuit.

Bowles, S., H. Gintis. 1976. Schooling in Capitalist America. London: Routledge \& Kegan Paul.

Brint, S., J. Karabel (eds.). 1989. The Diverted Dream: Community Colleges and the Promise of Educational Opportunity in America, 1900-1985. New York: Oxford University Press.

Breen, R., J. H. Goldthorpe. 1997. „Explaining Educational Differentials. Towards a Formal Rational Action Theory." Rationality and Society 9 (3): 275-305.

Breen, R., J. O. Jonsson. 2000. „Analyzing Educational Careers: A Multinominal Transition Model.“ American Sociological Review 65 (5): 754-772.

Duncan, O. D. 1961. „A Socioeconomic Index for All Occupations.“ Pp. 139-162 in A. J. Reiss (ed.). Occupations and Social Status. New York: Free Press of Glencoe.

Duncan, O. D. 1964. „Methodological Issues in the Analysis of Social Mobility." Pp. 51-97 in N. J. Smelser, S. M. Lipset (eds.). Social Structure and Mobility in Economic Development. Chicago: Aldine.

Duncan, O. D. 1966a. „Occupation Trends and Patterns of Net Mobility in the United States." Demography 3 (1): 1-18.

Duncan, O. D. 1966b. "Path Analysis: Sociological Examples.“ American Journal of Sociology 72 (1): 1-16.

Duncan, O. D. 1968. „Ability and Achievement.“ Eugenics Quaterly 15: 1-11.

Duncan, O. D. 1975. Introduction to Structural Equation Models. New York: Academic Press.

Duncan, O. D., D. L. Featherman, B. Duncan. 1972. Socioeconomic Background and Achievement. New York: Seminar Press.

Featherman, D. L., R. M. Hauser. 1978. Opportunity and Change. New York: Academic Press.

Fraser, S. (ed.). 1995. The Bell Curve Wars: Race, Intelligence and the Future of America. New York: Basic Books.

Ganzeboom, H. B., P. M. De Graaf, D. J. Treiman. 1992. „A Standard International Socio-Economic Index of Occupational Status." Social Science Research 21: 1-56.

Ganzeboom, H. B., D. J. Treiman, W. C. Ultee. 1991. „Comparative Intergenerational Stratification Research: Three Generations and Beyond." Annual Review of Sociology 17: 277-302.

Goldthorpe, J. 1996. „Class Analysis and the Reorientation of Class Theory: the Case of Persisting Differential in Educational Attainment." British Journal of Sociology 47 (5): 481-505.

Hauser, R. M. 1972. „Disaggregating a Social-Psychological Model of Education Attainment." Social Science Research 1: 159-188. 
Hauser, R. M., S. L. Tsai, W. H. Sewell. 1983. „A Model of Stratification with Response Error in Social and Psychological Variables." Sociology of Education 56 (1): 20-46.

Hayek, F. A. 1994. Právo, zákonodárstoí a svoboda. Praha: Academia.

Heath, B. S. 1983. Ways with Words: Language, Life and Work in Communities and Classrooms. Cambridge: Cambridge University Press.

Hellevik, O. 2007. „Margin Insensitivity and Analysis of Educational Inequality.“ Sociologický časopis / Czech Sociological Review 43 (6): 1095-1119.

Hutmacher, W., D. Cochrane, N. Bottani. 2001. In Pursuit of Equity in Education: Using International Indicators to Compare Equity Policies. Dordrecht, Boston, London: Kluwer Academic Publishers.

Illich, I. 2000. Odškolnění společnosti. Praha: Sociologické nakladatelství.

Katrňák, T. 2005. Tř́dní analýza a sociální mobilita. Brno: Centrum pro studium demokracie a kultury.

Kerckhoff, A. 1974. "Stratification Process and Outcomes in England and the U.S." American Sociological Review 39 (6): 789-801.

Kohn, M. L. 1977. Class and Conformity: A Study in Values. With Reassessment. Chicago: The University of Chicago Press.

Jöreskog, K. G. 1970. „A General Method for the Analysis of Covariance Structures.“ Biometrika 57: 239-251.

Jencks, Ch. 1972. Inequality: A Reassessment of the Effect of Family and Schooling in America. New York: Basic Books.

Jones, F. L. 1971. „Occupational Achievement in Australia and the United States: A Comparative Path Analysis." American Journal of Sociology 77: 527-539.

Lucas, S. R. 1996. "Selective Attrition in a Newly Hostile Regime: The Case of 1980 Sophomores." Social Forces 2: 511-533.

Lucas, S. R. 2001. „Effectively Maintained Inequality: Education Transitions, Track Mobility, and Social Background Effects." American Journal of Sociology 106 (6): 1642-1690.

MacLeod, J. 1995. Ain't No Makin' It: Aspirations \& Attainment in a Low-Income Neighborhood. Boulder: Westview Press.

Mare, Robert D. 1980. "Social Background and School Continuation Decisions." Journal of the American Statistical Association 75 (370): 295-305.

Mare, Robert D. 1981. „Change and Stability in Educational Stratification." American Sociological Review 46: 72-87.

Mare, Robert D. 1993. „Educational Stratification on Observed and Unobserved Components of Family Background." Pp. 351-379 in Y. Shavit, H. P. Blossfeld (eds.). Persistent Inequality. Changing Educational Attainment in Thirteen Countries. Boulder, San Francisco, Oxford: Westview Press.

Matějů, P. 2005. „Ke kořenům sociálně psychologického modelu sociální stratifikace: Otis Dudley Duncan a William Hamilton Sewell." Sociologický časopis / Czech Sociological Review 41 (1): 7-30.

Müller, W., W. Karle. 1993. „Social Selection in Educational Systems in Europe.“ European Sociological Review 9 (1): 1-23.

Nozick, R. 1974. Anarchy, State and Utopia. New York: Basic Books.

Powers, D. A., Y. Xie. 2000. Statistical Methods for Categorical Data Analysis. San Diego: Academic Press.

Raftery, A. E., M. Hout. 1993. „Maximally Maintained Inequality: Expansion, Reform, and Opportunity in Irish Education, 1921-75." Sociology of Education 66 (1): 41-62.

Rawls, J. 2001. Justice as Fairness: A Restatement. Cambridge, MA, London: Harvard University Press.

Ringen, S. 2000. „Inequality and Its Measurement.“ Acta Sociologica 43 (1): 1-14. 
Ringen, S. 2006. „The Truth about Class Inequality.“ Sociologický časopis / Czech Sociological Review 42 (3): 475-491.

Sewell, W. H., R. M. Hauser. 1972. „Causes and Consequences of Higher Education: Models of the Status Attainment Process." American Journal of Agricultural Economics 54: 851-861.

Sewell, W. H., V. P. Shah. 1967. „Socioeconomic Status, Intelligence, and the Attainment of Higher Education." Sociology of Education 40 (1): 1-23.

Sewell, W. H., A. O. Haller, G. W. Ohlendorf. 1970. „The Educational and Early Occupational Status Attainment Process: Replication and Revision." American Sociological Review 35 (6): 1014-1027.

Sewell, W. H., A. O. Haller, A. Portes. 1969. „The Educational and Early Occupational Attainment Process." American Sociological Review 34 (1): 82-92.

Shavit, Y., H. P. Blossfeld. 1993. Persistent Inequality. Changing Educational Attainment in Thirteen Countries. Boulder, San Francisco, Oxford: Westview Press.

Swift, A. 2003. How Not to Be a Hypocrite: School Choice for the Morally Perplexed Parent. London: Routledge.

Swift, A. 2004. „Would Perfect Mobility be Perfect?“ European Sociological Review 20: 1-11.

Treiman, D. J. 1970. „Industrialization and Social Stratification.“ Pp. 207-234 in E. O. Laumann (ed.). Social Stratification: Research and Theory for the 1970s. Indianapolis, New York: The Bobbs-Merrill Company.

Treiman, D. J., H. B. G. Ganzeboom. 2000. „The Fourth Generation of Comparative Stratification Research." Pp. 98-121 in M. S. R. Quah, A. Sales (eds.). The International Handbook of Sociology. London: Sage.

Treiman, D. J., K. Terrell. 1975. „The Process of Status Attainment in the United States and Great Britain." American Journal of Sociology 81: 563-583.

Willis, P. 1977. Learning to Labour: How Working Class Kids Get Working Class Jobs. Farnborough: Saxon House. 


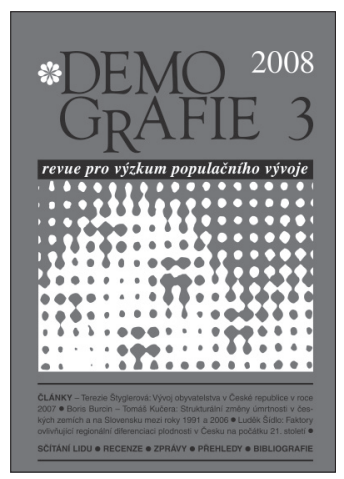

\title{
Půlstoletí časopisu
}

\section{DEMOGRAFIE \\ revue pro výzkum populačního vývoje}

\author{
Časopis Demografie, u jehož zrodu stál tehdejší \\ Státní úrad statistický a jeho předseda František Fajfr, \\ začal vycházet v roce 1959. \\ V letošním roce završuje padesátileté výročí své existence.
}

\section{Obsah aktuálního čísla 3/2008}

\section{ČLÁNKY}

Terezie Štyglerová: Vývoj obyvatelstva v České republice v roce 2007

Boris Burcin - Tomáš Kučera: Strukturální změny úmrtnosti v českých zemích a na Slovensku mezi roky 1991 a 2006

Luděk Šídlo: Faktory ovlivňujicí regionální diferenciaci plodnosti v Česku na počátku 21. století

\section{SČíTÁNÍ LIDU}

Josef Škrabal: Stav prípravy prǐštího sčítání lidu, domů a bytů

\section{RECENZE}

Ombudsman řeší problematiku trvalého pobytu (Bohdana Holá)

Nejen demografická historie Ruska v posledních dvou stoletích (Zdeněk Pavlík)

\section{ZPRÁVY}

Z České demografické společnosti - Kartografický den v Olomouci - Demografický vývoj nových spolkových zemí Německa - Mezinárodní statisticko-ekonomické dny na VSE

\section{PŘEHLEDY}

Rozvody v České republice $v$ letech 1991-2006 aneb co lze najít v Hlášení o rozvodu (Michaela Němečková) - Pohyb obyvatelstva České republiky ve městech nad 20 tisíc obyvatel v roce 2007 - Pohyb obyvatelstva České republiky podle krajủ a okresů v roce 2007 (Radek Havel)

\section{BIBLIOGRAFIE}

Časopis vychází čtyřǐkrát ročně, jeho plné znění za roky 2004-2006 je uveřejněno na internetu: http://www.czso.cz/csu/redakce.nsf///demografie.

Informace o předplatném podává a objednávky přijímá redakce.

Adresa redakce: Český statistický úrad, Redakce Demografie, Na padesátém 81, 10082 Praha 10 Výkonná redaktorka Věra Hrušková, tel.: 274052834, e-mail: vera.hruskova@czso.cz 